\title{
The Role of Monitoring and Evaluation on Assessing VVOB Rwanda Projects Paradigm in Improving the School Management and Leadership
}

\author{
Kibiriga Anicet ${ }^{1, *} \&$ Ndabananiye Aphrodis ${ }^{2}$ \\ ${ }^{1}$ Economics and Management of Education, Huazhong Normal University, China \\ ${ }^{2}$ Rwanda Education Board, Rwanda \\ *Corresponding author: Huazhong Normal University, China. E-mail: akibiriga@reb.rw \\ Received: November 10, 2017 Accepted: December 11, $2017 \quad$ Published: December 23, \\ 2017 \\ doi:10.5296/ije.v9i4.12397 \\ URL: https://doi.org/10.5296/ije.v9i4.12397
}

\begin{abstract}
In Rwandan School, Head Teachers are confronted with a variety of issues as they provide leadership and management to their schools. This study utilized a mixed methods approach to explore the role of M\& E on assessing VVOB Rwanda Projects paradigm in improving the school Management and Leadership in order to deal with those issues. Quantitative methods were coupled with qualitative methods to obtain more complete picture of conventional monitoring and evaluation practices and as validity check to balance deficiencies that were found. Self-Administered Questionnaire was made by two categories of questionnaires such as the one concerning monitoring and evaluation in VVOB Rwanda Programme with challenges encountered. Administered questions to the VVOB staff taken as sample. While the other category was about the extent to which VVOB projects has helped in improving the school management and leadership. The questions of this category are based on eight (8) dimensions of successful leadership (questions that assess HTs) and Training methods that can be used when holding meetings by Sector Education Officers (Questions that assess SEOs). Research findings have shown that VVOB's monitoring and evaluation techniques are conducive to the project success. The study shown that the most challenges found in M\&E are inadequate financial resources, fear of evaluation of project implementers thinking that it is the way of judging them and sometimes causing them to have punishment like cutting the project funds. Finally VVOB Rwanda projects have significantly improved the school leadership and management as it was shown by the difference about performance of school leadership dimensions of trained Head teachers and Sector Education officers comparing with those who were not trained. Strategies for improving schools leadership have been stalled as they have been mentioned by Head teacher.
\end{abstract}

Keywords: Head teacher, Leadership, Management, Monitoring, Evaluation 


\section{$\Lambda$ Macrothink}

\section{Introduction}

\subsection{Background of the study}

Capacity development is a fundamental part of the mandates of many international organizations or international projects. Much of their work aims to strengthen national capacities through training, technical advice, exchange of experiences, research, and policy advice. Yet there is considerable dissatisfaction within the international community regarding the impact of many such interventions. The activities have usually strengthened the skills of individuals, but have not always succeeded in improving the effectiveness of the ministries, institutions and other organizations where those individuals are working. These shortcomings demand investigation in order to strengthen capacity development policies and strategies.

In education planning and management, capacity development implies a focus on the existing capacities of governments and how these capacities can become strengthened on all levels the individual, the organizational and the institutional, as well as the broader system context. Governments, donor agencies and international organizations involved in development are increasingly putting an emphasis on capacities as key to sustainable development in general and in reaching the Education for All (EFA) goals in particular.

In reality, this is yet to be the case, precisely because the state in many countries does not yet play its developmental role fully. In public sectors such as health and education, development non-government organizations (NGOs) have been occupying the role of main service providers over the past few years. Often replacing the role of the government on the ground, especially in remote rural areas, NGOs and international projects have traditionally assumed a gap-filling role that has sometimes created conflicting relations with governments. In this context, their strategies and activities are of interest in so far as they have an impact on governmental capacity development in the education sector. Indeed, while the continuation of their gap-filling role depends on the government's lack of capacity, NGOs increasingly demand that governmental priorities change by paying more attention to those people who have not yet been reached. They act therefore as innovators, critics, advocates and policy partners. The capacity development concept and the need to focus on strengthening government capacity provide NGOs with new challenges. The possible contradictions between capacity development as a developmental paradigm and NGOs' role as gap fillers correspond to the tensions between the new and the traditional roles of NGOs. This raises one issue: What impact did VVOB projects in improving the school management and leadership in Rwandan schools?

Our focus in this paper will be on VVOB Rwanda Projects activities in Education sector, especially on school management and leadership.

\subsection{Purpose/Aim of the Study}

The role and influence of international projects and NGOs in relation to capacity development and education is of interest because of the incontestably important role of these organizations in development in general, and in the education sector in particular. Seen from an increasingly dominating capacity development perspective, the changing roles of NGOs or 
international projects pose a number of questions aimed at discerning their function and impact on the education sector: how do NGOs conceive of and adapt their activities to the concept of capacity development?

In this new environment, schools and schooling are being given an ever bigger job to do. Greater decentralization in many countries is being coupled with more school autonomy, more accountability for school and learning outcomes, and a better use of the knowledge base of education and pedagogical processes. It is also being coupled with broader responsibility for contributing to and supporting the schools' local communities, other schools and other public services. This study argues that to meet the educational needs of the $21^{\text {st }}$ century the Head teachers in primary and secondary schools must play a more dynamic role and become far more than an administrator of top-down rules and regulations.

Schools and their governing structures must let school leaders lead in a systematic fashion and focus on the instructional and learning processes and outcomes of their schools. Today's Rwandan school administrators (Head teachers, Deputy head teachers.....) are confronted, on a daily basis, with a variety of issues from how to implement the competence-Based Curriculum(CBC), ICT integrated, inclusive education, to handling irate parents, managing school feeding program, to supporting overwhelmed teachers. How they react to these issues, to a great extent, determines their success or failure as school administrators. Building principals are charged with being the instructional and visionary leaders that every community wants and with successfully managing the day-to-day happenings that occur in every school. What role should International projects play to help the school administrators to deal with $21^{\text {st }}$ requirements?

In this context, the researcher would investigate the role of M\&E in success of VVOB Rwanda project working with the main objective of improving school leadership and management. In many countries, the Ministry of Education provides teacher training — but those may occur as sporadically as once every five years. Contrary to Rwanda, the Ministry of Education through Rwanda Education Board(REB) organize on quarterly basis teacher training for improving their professional skills, however, according to the need of teacher developments, those training are not sufficient, reason why more than 50 international projects have been welcomed in education sector, such as Education Development Center, Inc (EDC) / Akazi Kanoze, A Partner in education, Action Aid International Rwanda, ADRA, Aegis Trust, African Development Foundation, African Innovation Prize, Direct Aid, Concern Worldwide, Joint Aid Management International, Plan International Rwanda, Right To Play, Rwanda AID, The Wellspring Foundation for Education, Volunteer Service Overseas, World Vision International, Save the Children, Handicap International, Family for Health International (FHI360)**, VVOB, British Council, Forum for African Women Educationlists Rwanda (FAWE RWANDA), Millenium Village Project, Sustainable Health Enterprise(SHE) etc.

This paper will be focused on M\&E and school management and leadership. It is in this context that among those 50 educational interventional projects, VVOB Rwanda Projects has been the center of interest in this paper. 


\subsection{Research Questions}

This study will be guided by the following research questions:

$>$ What factors that play role in effective and efficient project success?

$>$ Does the M\&E environment of VVOB Rwanda projects conducive and good for M\&E?

$>$ What are the challenges faced by VVOB Rwanda's Monitoring and Evaluation Techniques?

$>$ To which Extent do VVOB Projects improved the School Leadership and Management?

\section{Literature Review}

The purpose of this section is to discuss the terms that are used in our research namely; leaderships, management and monitoring and evaluation.

\subsection{Leaderships and Management}

The literature has a wealth of information about these concepts (M\&E and Leadership and management) and yet the message can be quite confusing.

Management and leadership are two terms that are frequently used interchangeably, but, they are not the same. They have quite distinct meanings. The two do have similarities but they also have important differences.

Adair (2002) used the original word meanings to emphasise this: Leading is about deciding direction, coming from an Anglo-Saxon word meaning the road or path ahead; knowing the next step and then taking others with you to it. Managing is a later concept, from Latin 'manus', meaning hand, and more associated with handling a system or machine of some kind. The same notion of looking outwards or inwards is captured by Bennis (2003):

I tend to think of the differences between leaders and managers as the differences between those who master the context and those who surrender it. www.stellarleadership.com (retrieved on 20.12.2017)

Kotter (1990) says that management tries to establish security and order, whereas leadership has the goal of promoting change and fluidity within organizations. Kotter proposed that the main function of managers is to drive consistency, which in turn should lead to an efficient-running organization. However, leaders were determined by Kotter (2001) to do the converse to this, by seeking "continual adaptive change". Kotter did not mean that leaders were looking for change for change's sake, rather, in such unpredictable times continual change is required for an organization to even survive at all.

While Lalonde (2010) states that, Management is concerned primarily with getting the work of the organization completed in an efficient and effective manner. Its focus is typically on the day to day functioning of the organization giving primary attention to getting the job done. Leadership, on the other hand focuses attention on the future or what needs to be done. Its 
focus is on vision and empowerment and reaching goals (Lalonde, 2010). While the manager will direct the workforce to complete the required tasks the most efficient way, the leader tends to inspire or venture into new ways of doing things. James Tobin (2014). Leadership is viewed as an influence process while management is seen as utilizing control (Catano \& Stronge, 2007). The leader seeks to find new solutions to bring about improvement while the manager seeks to assure that all participants remain "on task" and meet their required goals.

The leader is concerned with understanding and changing others beliefs and with changing the status quo. The manager, however, advocates stability and carries out his responsibilities by exercising authority to get the goals accomplished (Lunenburg, 2011).

Managers do things right, but leaders do the right things. This phrase has been attributed to both Peter Drucker and to Warren Bennis, both of whom have contributed significantly to the literature on leadership and management (Bennis, 1989; Drucker, 1966). It expresses in simple and direct terms the differences in the two functions that administrative or executive personnel engage in. The manager is required to get things done properly, and the leader focuses attention on what really needs to be done.

According to Stephen \& Timothy (2012) in the organizational behavior book, where they wrote that John Kotter of the Harvard Business School argues that management is about coping with complexity. Good management brings about order and consistency by drawing up formal plans, designing solid organization structures, and monitoring outputs against the planed one.

Leaders establish direction by developing a vision of the future, and then they align people by communicating this vision and inspiring them to overcome hurdles. We define leadership as the ability to influence a group toward the achievement of a vision or set of goals. The source of this influence may be formal, such as that provided by managerial rank in an organization. But not all Leaders are managers, nor, for that matter, are all managers leaders (Lunenburg, 2011). Just because an organization provides its managers with certain formal rights is no assurance they will lead effectively. Organizations/schools need strong leadership and strong management for optimal effectiveness. We need leaders today to challenge the status quo, create visions of the future, and inspire organizational members to want to achieve the visions. We also need managers to formulate detailed plans, create efficient organizational structures, and oversee day-to-day operations.

One of the first researchers to examine the differences between management and leadership was Abraham Zaleznik of Harvard University. In 1977 he published an article in the Harvard Business Review in which he shared his belief that both leaders and managers were important to organizations even though their contributions differed. Managers tend to focus their attention on getting tasks completed in an efficient and effective manner whereas leaders were more focused on trying to understand the people in the organization and to gain their trust. Managers tended to rely on authority to accomplish their tasks whereas leaders tended to utilize persuasion and influence (Zaleznik, 1997).

In a more recent discussion of leadership and management, leaders were described as being 
more focused on people where the manager was focused on tasks. The leader tends to look outward, in a more expansive way whereas the manager's focus was inward and on the specific task or tasks that needed to be completed. Leaders focused their attention on articulating a vision while the manager was clearly more focused on executing plans (Lunenburg, 2011). It is important to note, however, that Zaleznik and Lunenburg (1997) believed that both leaders and managers were needed for optimal effectiveness in organizations.

Other new definitions of leadership begin with the agreement that leadership is not a set of personal qualities with which certain individuals are imbued and which enable them to sweep into school, clear away disorder and confusion, and lead the school through the sheer force of personality. Zaleznik (1997) commented, ' in curious ways, people tend to aggrandize the role of leaders. They tend to exaggerate the capacity of leaders to influence events". Donaldson (2001) states that the conception of leaders as heroic "violates, when applied to public schools, the democratic values system and distributed power arrangements we find there". Finally, Elmore (2000) says, "Contrary to the myth of visionary leadership that pervades American culture, most leaders in all sectors of society are creatures of the organizations they lead". He believes this phenomenon is particularly true in public schools, where leaders almost exclusively come from the ranks of teachers and, therefore, are "well socialized" into the status quo of the current school organization.

Elmore (2000) argues that we need to "de-romanticize" leadership to make large-scale improvements in school organizations. Rather than the illusion of the all-powerful personality who can "embody all the traits and skills that remedy all the defects", he suggests a definition of leadership that focuses on improvement in instruction and that distributes leadership throughout the organization. The new definition of school leadership that Elmore advocates, though, does not conform to the traditional bureaucratic-rational conception of the role. In the classic leadership model described earlier, the principal controls specific functions in the school. In the school committed to instructional improvement, "most of the knowledge required for improvement must inevitably reside in the people who deliver instruction, not in the people who manage them". Therefore, the principal cannot control teaching and learning. Elmore believes that, instead, the principle's role is to guide and direct them through the processes of distributive leadership. (p 200) Thomas, Paul et al (2011) in the Educational Governance and Administration book ( $6^{\text {th }}$ Edition $)$

On the other hand, it is noted that in OECD countries as elsewhere in the world, school leaders face challenges due to rising expectations for schools and schooling in $21^{\text {st }}$ century characterized by technological innovation, migration and globalization. As countries aim to transform their educational systems to prepare all young people with the knowledge and skills needed in this changing world, the roles of school leaders and related expectations have changed radically. They are no longer expected merely to be good managers; effective school leadership is increasingly viewed as key to large-scale education reform and to improved educational outcomes. OECD (2009). Do VVOB projects contribute to the formation of the School Administrators we need in this $21^{\text {st }}$ century? Before looking for the answer to this question, let us start by defining the key terms. 


\subsection{Monitoring \& Evaluation}

$\mathrm{M} \& \mathrm{E}$ is an embedded concept and constitutive part of every project or program design.

Monitoring is the systematic and routine collection of information from projects and programmes for four main purposes: to learn from experiences, to improve practices and activities in the future; to have internal and external accountability of the resources used and the results obtained; to take informed decisions on the future of the initiative; to promote empowerment of beneficiaries of the initiative.

Monitoring is checking progress against plans. Monitoring is also a periodically recurring task already beginning in the planning stage of a project or programme. Monitoring allows results, processes and experiences to be documented and used as a basis to steer decision-making and learning processes.

While, Evaluation is assessing, as systematically and objectively as possible, a completed project or programme (or a phase of an ongoing project or programme that has been completed). Evaluations appraise data and information that inform strategic decisions, thus improving the project or programme in the future.

Evaluations should help to draw conclusions about five main aspects of the intervention: relevance, effectiveness, efficiency, impact and sustainability. Heerkens, G. (2002).

\section{Research Methodology}

\subsection{Research Design}

The research design that was used in this study was descriptive survey whereby a group of people or items is studied by collecting and analyzing data from only few people or items considered being representatives of entire group. In this research quantitative methods were coupled with qualitative methods to obtain more complete picture of conventional monitoring and evaluation practices and as validity check to balance deficiencies that were found.

\subsection{Target Population}

The target population in this research was made up of VVOB projects implementers that are seven (7) individuals working at VVOB Head Office; seven (7) individuals working in Learning Outcome in Primary Education (LOPE) Programme and three (3) who make TVET School leadership team whereas projects beneficiaries. There are also project beneficiaries. Those include all SEOs, Head teachers in Rwanda. And lastly other project stakeholders such as donors represented by DFID-UKAID (one respondent) and MINEDUC (one respondent) and its institutions especially REB (one respondent) and WDA (one respondent).

\subsection{Sampling Techniques}

In order to ensure representative-ness of the samples, purposive sampling was chosen, where the respondent who gave relevant information relative to the achievement of project success through monitoring and evaluation in the group of population was selected by the researcher. 


\section{MlMacrothink}

International Journal of Education

ISSN 1948-5476

2017, Vol. 9, No. 4

This technique was chosen because the researcher wanted to find the relevant population who has the right information according to their duties and responsibilities.

\subsection{Sample Size}

The purposive sampling was used whereby key persons considered as respondents whose job are relative to the $M \& E$ activities for getting relevant information related to the study. The sample is made up of eight (8) selected VVOB projects implementers such as Programme manager, Deputy programme manager, Administration and Finance manager at the Head Office, Inset and Preset and M\&E advisor and School Leadership Advisor in Learning Outcomes in Primary Education (LOPE) programme and finally TVET School Leadership Team that is made up of Advisor in School Leadership and Capacity Building; TVET School management Expert and TVET School Management and School Leadership Technical Assistant on one hand. On the other hand there are projects beneficiaries that include sixteen (16) SEOs and sixteen (16) Head teachers from the sectors according to the area covering by VVOB programme. For other stakeholders there are 1 respondent who is the VVOB focal point person from REB, 1 respondent from WDA in charge of educational project, 1respondent in charge of education NGOs from MINEDUC Headquarters and 1 respondent from donors, the UK Government's Department for International Development (DFID). The total number is 44 respondents including project implementers, beneficiaries, and other stakeholders.

\subsection{Data Collection Methods}

The study used survey techniques; questionnaires and interviews were used to collect primary data. Both secondary and primary data collection methods were used for getting valid and reliable results.

\subsection{Data Collection Instruments}

The self-Administered Questionnaire was made by two categories of questionnaires such as the one concerning monitoring and evaluation in VVOB Rwanda Programme with challenges encountered. This category of questions was administered to the VVOB staff taken as sample. While the other category which is very important in this paper is about to which extent VVOB projects has helped in improving the school management and leadership. The questions of this category are based on eight (8) dimensions of successful leadership (questions that assess HTs) and Training methods that can be used when holding meetings by Sector Education Officers (SEOs) (Questions that assess SEOs). The questions that assess head teachers were administered to teachers and other school community members of the very school whereas questions that assess SEOs when holding meetings and trainings were administered to their relative HTs. Among the questions there are close ended questions and open ended ones. Interview was done for the project stakeholders such as Donors represented by DFID, interviewees from MINEDUC, REB and WDA.

\subsection{Administration of Data Collection Instruments}

Self-Administered Questionnaires were given face to face to respondent individually for 
ensuring that they reach to each respondent and for explaining how they should carefully fill questionnaires and sent them to researcher within one week. This increased the quality of information gotten from the respondents. Likert item questionnaires with five-levels format were given to the respondents who answered the questions about the assessment of how successfully the HTs achieved leadership and management according to eight successful school leadership dimensions. Interview also was used for other stakeholders such as Donors, Ministry of Education (MINEDUC), Rwanda Education Board (REB) and Work Development Authority (WDA).

\subsection{Reliability and Validity}

Validity of a measure is how well it fulfills the function for which it is being used. In other words, validity of a measuring instrument is its ability to measure what it is intended to measure. The researcher ensured content validity of the instrument by ensuring that the questions or items in it conform to the degree to which a test samples the content area which is to be measured. It is determined through expert judgment by carefully and critically examining or inspecting the items that make the instrument (Kothari, 2005).

Reliability refers to the dependability or trustworthiness in the context of a measuring instrument. It is the degree to which the instrument consistently measures whatever it is measuring. Hence, reliability in educational an instrument or test in order to obtain information (Kothari, 2005). According to Gay and Airasian (2003), 'reliability is the degree measuring' among the questions there are close ended questions and open ended ones.

Interview was done for the project stakeholders. The questions were built in such way that they are consistent to the content and measure what they are intended to measure thus valid and reliable answers.

\subsection{Data Analysis Procedure}

The data collected was processed for analysis and then later actually analyzed. The collected data was edited, categorized or coded, computerized and Likert scale was also another way that helped to analyze data. Editing was another way that was used to verify the coherence of respondents in answering the questionnaire items. Logical analysis was among other approaches that were used. Others include tabulating and statistical evaluation of data accuracy, promptness and reliability. Errors in completed questionnaire items were identified and eliminated. Coding was used to summarize and simplify the work of processing data, enable the classification of answers accordingly and facilitate the researcher judgment and drawing conclusions. The collected data was analyzed with help of tables in order to count the responses and make statistical frequency distribution. Putting the information provided by the respondents in tables together with corresponding ratings in terms of percentage were among the approaches that were used. As for Likert scale this is the approach used to scaling responses whereby respondents specify their level of agreement or disagreement on a symmetric agree-disagree scale for a series of statement. One of the formats of Likert scale used was five-levels format that are 1: strongly disagree, 2: Disagree, 3: Neutral (Neither agree or disagree), 4: Agree and 5: Strongly agree. This is the format that was used in this 


\section{Macrothink}

research study when assessing the improvement of school leadership and management.

\subsection{Ethical Considerations}

The prospective respondents were told the purpose of the study and the researcher informed the respondents that the research is only carried out for academic purposes, and the participation was voluntary. The researcher tried to protect respondents' identities.

\section{Research Findings}

\subsection{Demographic Characteristics of Respondents}

The following table 1 explains how gender balance has been used in this research study.

Table 1. VVOB's Staff and Other Stakeholders' Gender Identification

\begin{tabular}{llc}
\hline Sex & Number of Respondents & Percentage \\
\hline Female & 6 & $50 \%$ \\
Male & 6 & $50 \%$ \\
Total & $\mathbf{1 2}$ & $\mathbf{1 0 0 \%}$ \\
\hline
\end{tabular}

Source: Field Data

Table 1 shows that VVOB Rwanda respect the gender balance because the respondents are $50 \%$ male and $50 \%$ female. It shows that there is also gender balance of stakeholders. This means that the respondents are 50\% male and 50\% female. For Head Teachers and SEOs it is not necessary to mention gender items because the successful school leadership and management does not require any gender.

\subsection{Educational Level}

Questionnaires were given to different individual with different educational backgrounds. The following table explains briefly the educational level of the respondents.

Table 2. Educational Level

\begin{tabular}{lcccccc}
\hline $\begin{array}{l}\text { Educational } \\
\text { level }\end{array}$ & $\begin{array}{c}\text { VVOB } \\
\text { staff }\end{array}$ & Stakeholder & SEOs & H/T & Total & $\begin{array}{c}\text { Percent } \\
\text { age (\%) }\end{array}$ \\
\hline Secondary & 0 & 0 & 0 & 10 & 10 & $\mathbf{2 3 \%}$ \\
Diploma(A1) & 0 & 0 & 0 & 4 & 4 & $\mathbf{9 \%}$ \\
Bachelor's & 3 & 3 & 16 & 2 & 24 & $\mathbf{5 5 \%}$ \\
Master's & 4 & 1 & 0 & 0 & 5 & $\mathbf{1 1 \%}$ \\
PhD & 1 & 0 & 0 & 0 & 1 & $\mathbf{2 \%}$ \\
Total & $\mathbf{8}$ & $\mathbf{4}$ & $\mathbf{1 6}$ & $\mathbf{1 6}$ & $\mathbf{4 4}$ & $\mathbf{1 0 0 \%}$ \\
\hline
\end{tabular}

Source: Field data 


\section{$\triangle$ Macrothink}

Table 2 shows Educational levels such as Secondary Education certificate (A2), Diploma (A1), Bachelor's Degree (A0), Master's Degree and PhD. The big numbers of respondents24 that represent $55 \%$ of the total respondents are Bachelor's Degree holders. 5 Masters that represents $11 \%$ of total number of respondents, and one $\mathrm{PhD}$ holder that represents $2 \%$ of the total number of respondents. This means that the information from the respondents will be of good quality because a big number of respondents know about research, how to collect data, and the importance of giving accurate and precise data as well as they have done their own research by the end of their academic level that they have.

\subsection{Working Experiences}

Working experience is one of more important pillar of performing well in job. It is in that regard that the researcher wanted to highlight the working experience of the respondents. This can identifies the performance of the job that one is assigned to do. Table 3 below identifies the respondents' working experience in this study.

Table 3. Working Experiences

\begin{tabular}{lcccccc}
\hline Experiences & VVOB staff & Stakeholder & SEO & H/T & Total Percentage \\
\hline 0-2years & 0 & 0 & 0 & 0 & 0 & 0 \\
3-5 years & 1 & 2 & 16 & 11 & 30 & 68 \\
6-10 years & 3 & 1 & 0 & 5 & 9 & 20 \\
11-15 years & 2 & 1 & 0 & 0 & 3 & 7 \\
Above 15 years & 2 & 0 & 0 & 0 & 2 & 5 \\
Total & $\mathbf{8}$ & $\mathbf{4}$ & $\mathbf{1 6}$ & $\mathbf{1 6}$ & $\mathbf{4 4}$ & $\mathbf{1 0 0}$ \\
\hline
\end{tabular}

Source: Field Data

Table 3 mentions that the working experience of the respondents is mainly in range of between three and five years that represent $68 \%$ of the total respondents. This is a good target population because working experience of between three and five years implies that the respondent know very well what they are supposed to do and how to achieve their set objectives.

\subsection{Presentation of Findings}

In this study data collection was done based on the research questions and then findings are relative to the VVOB monitoring and evaluation techniques and their related challenges and the extent to which VVOB improved the school leadership and management in comparing both; group of SEOs and HTs trained (group A) through VVOB projects and Control group (Group B) that has SEOs and HTs that are not trained. The difference shown identifies the success of VVOB projects. 


\subsection{VVOB Rwanda Activities and Resources}

Among thirty district of the whole country VVOB Rwanda projects are now working in twenty districts. According to the province there are in number of the following:

\begin{tabular}{lll}
\hline S/N & Province & Number of District \\
\hline 1 & Kigali City & 1 \\
2 & Western Province & 5 \\
3 & Northern Province & 4 \\
4 & Southern & 6 \\
5 & Eastern & 4 \\
& TOTAL & $\mathbf{2 0}$ \\
\hline
\end{tabular}

VVOB was founded by the Flemish and the Belgian governments; it is not associated to any religious body. The organization is carrying out its projects in Rwanda long ago. It spent more than nine years and more than 250,000 Euro in its projects. As well as VVOB was founded by the governments, it is also funded by the government bodies. The Organization owns many types of equipment such as for instance computers, video equipment, and cars. Lastly but not least, VVOB Rwanda has different three categories of employees such as Permanent staff that are between seven and twelve individuals, temporary staff that are more than fifteen and voluntary staff that are less than seven. Rwanda, V (2012). Annual Report. Kigali. VVOB

\subsubsection{Monitoring and Evaluation Plan}

In the assessment of VVOB's project monitoring and evaluation techniques researcher first of all considers how there is M\&E planning activities. The table 4 below represents M\&E plan items. These are conducting study to establish baseline data before implementation; have plan that guides $\mathrm{M} \& \mathrm{E}$; only project implementers are involved in the planning of M\&E; all related aspects are involved in M\&E plan; there is special budget for M\&E activities; M\&E activities are normally allocated 5\%-9\% of the total budget; logical Framework is used to help M\&E; $\mathrm{M} \& \mathrm{E}$ activities are parts of project schedule; two over six ways of disseminating $\mathrm{M} \& \mathrm{E}$ findings.

Table 4 shows that M\&E planning item that has the minimum level of achievement in all related aspects are involved in M\&E plan, 5 respondents over 8 respondents represented by $62.5 \%$. These aspects are: Data to be collected, frequency of data collection, an individual in charge of $\mathrm{M} \& \mathrm{E}$, schedule of $\mathrm{M} \& \mathrm{E}$ activities, plan for dissemination of findings, individuals for specific M\&E activities. Four items have $8 / 8$ respondents to mean $100 \%$ achieved. These are item $\mathrm{n}^{0} 3,5,6$ and 7 . Two over six ways of disseminating M\&E findings, these are Report to donors and community meeting. The failure of not involving project stakeholders in the planning of $M \& E$ activities was identified. The general achievement of the M\&E planning activities is equal to $88.8 \%$. This implies that planning M\&E is well done by VVOB Rwanda projects and this is very crucial because it is the beginning of performing well result based M\&E. 
Table 4. Monitoring and Evaluation Plan, $n=$ Number of respondents

\begin{tabular}{lll}
\hline Question Items & $\begin{array}{l}\text { Frequencies } \\
(\mathbf{n = 8 )}\end{array}$ & Percentage \\
\hline Conducting study to establish baseline data before implementation. & 6 & $\mathbf{7 5 \%}$ \\
Have plan that guides M\&E. & 7 & $\mathbf{8 7 . 5 \%}$ \\
Only project implementers are involved in the planning of M\&E. & 8 & $\mathbf{1 0 0 \%}$ \\
All related aspects are involved in M\&E plan. & 5 & $\mathbf{6 2 . 5 \%}$ \\
There is special budget for M\&E activities. & 8 & $\mathbf{1 0 0 \%}$ \\
M\&E activities are normally allocated 5\%-9\% of the total budget. & 8 & $\mathbf{1 0 0 \%}$ \\
Logical Framework is used to help M\&E. & 8 & $\mathbf{1 0 0 \%}$ \\
M\&E activities are parts of project schedule. & 7 & $\mathbf{8 7 . 5 \%}$ \\
Two over six ways of disseminating M\&E findings. & 7 & $\mathbf{8 7 . 5 \%}$ \\
Overall & $\mathbf{6 4}$ & $\mathbf{8 8 . 8 \%}$ \\
\hline
\end{tabular}

Source: Field Data

\subsubsection{Projects Monitoring and Evaluation Process Implementation}

After planning M\&E, it is then the implementation of what was planned. Implementation is considered as the practical phase whereby words are put into practice and it is where the difference of a good planner and an achiever is found. This is because one can plan well but not achieves what was planned. In addition to that, the potentials of achieving objectives are found in putting into practices what was said. Table 5 shows how items related to M\&E implementation are put into practice in VVOB Rwanda projects.

Table 5 shows that the first three items such as M\&E of projects finances, Monitoring and controlling of the field staff activities, M\&E of project activities are done after three months as it is shown by the percentage from $75 \%$ and above. It shows also that Monitoring of Organization's equipment is done every 12 months. Four out of five methods are used when collecting project M\&E data as it is confirmed by $6 / 8$ respondents that represent $75 \%$. Those methods are questionnaires, participant observation, in-depth interviews and focus group interviews. Technology is used in all M\&E activities at 100\% level. At the level of $87.5 \%$ six out of seven types of monitoring are used in the project implementation, these are results monitoring; process (activity) monitoring; compliance monitoring; context (situation) monitoring; financial monitoring; organizational monitoring while all types of evaluations are done at $75 \%$. Three over five evaluation approaches are used at $87.5 \%$. Those three approaches are the objective-oriented approach, the decision-making (management) approach) and the expertise approach. The rate that shows the role of $\mathrm{M} \& \mathrm{E}$ for achieving projects objectives is $30-40 \%$. This was confirmed $6 / 8$ respondents, that is $75 \%$ for the reasons that $\mathrm{M} \& \mathrm{E}$ is very important for the project to be achieved in a such way that designing the M\&E system and indicators chosen helps to clarify the logic of the program and the objectives; M\&E improve the implementation through early warning of problems and measuring whether the planned and implemented activities are producing the intended outcomes and whether additional or revised activities are necessary; the outcomes of 
evaluation demonstrate the effectiveness of a program to outsiders such as potential donors, government officials. The other factors that play role in effective and efficient project success that mentioned are resources (human resources and financial resources for M\&E), effective planning, and competent staff.

Table 5. Projects Monitoring and Evaluation Process Implementation

\begin{tabular}{lll}
\hline Question Items & $\begin{array}{l}\text { Frequencies } \\
(\mathbf{n}=\mathbf{8})\end{array}$ & $\begin{array}{l}\text { Percentage } \\
(\%)\end{array}$ \\
\hline $\begin{array}{l}\text { M\&E of projects finances is done every 3 months. } \\
\text { Monitoring and controlling of the field staff activities is done }\end{array}$ & 7 & $\mathbf{8 7 . 5}$ \\
every 3 months. & $\mathbf{1 0 0}$ \\
M\&E of project activities is done every 3 months. & 6 & $\mathbf{7 5}$ \\
Monitoring of Organization's equipment & 8 & $\mathbf{1 0 0}$ \\
four out of five methods are used while collecting M\&E data. & 6 & $\mathbf{7 5}$ \\
Technology is used in all M\&E activities. & 8 & $\mathbf{1 0 0}$ \\
$\begin{array}{l}\text { Six out of seven types of Monitoring are used in the project } \\
\text { implementation. }\end{array}$ & 7 & $\mathbf{8 7 . 5}$ \\
$\begin{array}{l}\text { All types of evaluations are used in the projects lifecycle. } \\
\text { Three over five evaluation approaches are used. }\end{array}$ & 6 & $\mathbf{6 5}$ \\
$\begin{array}{l}\text { The rate that shows the role of M\&E for achieving projects } \\
\text { objectives is 30-40\%. }\end{array}$ & 6 & $\mathbf{8 7 . 5}$ \\
$\begin{array}{l}\text { External evaluators are involved few times when conducting } \\
\text { evaluations. }\end{array}$ & 6 & $\mathbf{7 5}$ \\
$\begin{array}{l}\text { Documenting lesson learnt on the project implementation. } \\
\text { Overall }\end{array}$ & 8 & $\mathbf{7 5}$ \\
\hline
\end{tabular}

$n$ : Number of respondents.

Source: Field Data

The second failure found is that External evaluators are involved few times when conducting evaluations. This is shown by the confirmation of $6 / 8$ respondents either $75 \%$. And lastly but not least is that documenting lesson learnt on the project implementation is highly done at $100 \%$ because M\&E report teaches the project implementers about the weaknesses and this gives opportunity to handle them, it promote accountability of the project team and stimulate performance, $M \&$ E report document and explain the reasons why project activities succeed or fail, briefly by learning lessons from mistakes that might have been made, project implementers will be empowered to improve the future project planning and implementation.

\subsubsection{The M\&E Environment of Projects}

About the M\&E environment of projects where there is Finance to carry out M\&E, reporting requirements, demonstration of the long term impacts, and expert personnel in M\&E. See table 6 below. 
Table 6. The M\&E Environment of Projects

\begin{tabular}{lcl}
\hline Questions Items & $\begin{array}{l}\text { Frequencies } \\
(\mathbf{n = 8 )}\end{array}$ & Percentage \\
\hline Finance to carry out M\&E activities is rarely adequate. & 6 & $\mathbf{7 5 \%}$ \\
Different donors have different reporting requirement. & 5 & $\mathbf{6 2 . 5 \%}$ \\
M\&E reporting requirement are strict. & 6 & $\mathbf{7 5 \%}$ \\
Demonstrating the long term impact of the projects is straightforward. & 7 & $\mathbf{8 7 . 5 \%}$ \\
There is M\&E expertise in organization. & 6 & $\mathbf{7 5 \%}$ \\
Overall & $\mathbf{3 0}$ & $\mathbf{7 5 \%}$ \\
\hline
\end{tabular}

$n$ : Number of respondents

Source: Field Data

Table 6 shows that the funds to carry out M\&E is rarely adequate as it is confirmed by $6 / 8$ respondents either $75 \%$ this is considered as the third failure. It shows also that different donors have different reporting requirement at $62.5 \%$ and the later are strict as at $75 \%$. In M\&E demonstration of long term impacts of projects is done at $87.5 \%$ and there is expertise

in VVOB at $75 \%$. Generally the M\&E environment of VVOB Rwanda projects is conducive and good for $\mathrm{M} \& \mathrm{E}$ because it presents reports required by donors and other stakeholders and demonstrates long term impacts.

\subsubsection{Results from the Stakeholder' Interview}

Response to interview question number one about VVOB projects initial reflections on measurable impacts is that Good conception of project whereby its implementation is leading to efficient management of school leaders in collaboration with members of school management committee. Project were well initiated and measurable impacts are clear based on eight dimensions of successful leadership and the students performances in different tests even in National Examinations.

Interview question number two about VVOB projects progress, efficiency and effectiveness, response is that Good implementation supported by monitoring and evaluation that needed for following up day to day activities for further being sure that the projects were in the way of achieving objectives.

Question number three about extent to which there is potential for VVOB projects in relation to the Government of Rwanda's policies, proved that as well as successful school leadership and management is needed in the whole country, these are very needed expended in the entire country. The potential is already highlighted in the way that the projects help to improve the education quality, equity and access as education policies, thus the achievement of education sector objectives of the country.

Last question about the rate that shows the role of $\mathrm{M} \& \mathrm{E}$ in achieving project objectives is between $30 \%-40 \%$ as confirmed by three over four respondents either $75 \%$. The reasons given are that $\mathrm{M} \& \mathrm{E}$ helps: planning, monitor and improve project progress, to measure and 
increase project impact, as instrument for advocacy. Other factors that help for achieving project objectives are clear vision and objectives, sufficient financial resources, competent staff and proper planning.

3.5.5 Challenges faced by VVOB Rwanda's Monitoring and Evaluation Techniques and Solutions Applied

There are many challenges but the most challenges encountered are: duration of the project is too short to measure quantitative learning 'higher pin u the chain' from head was part teacher of the M\&E to trajectory in order to be able to come up with plausible conclusions and recommendations. Turnover of Head Teachers and SEO's; for head teachers to new comers, for new as coming budgeted to give SEO's good introductory extra guidance. Less priority is given in the line of participation, than is needed. Cultural barrier for using the coaching concept. During the coaching process was monitored and evaluated. Where happened within was 'priori adjusted to the cultural context.

Involving where possible and informing College of Education, University of Rwanda systematically from the beginning of the project facilitated the constitution of an opportunity like that. Not enough budget available for an up scaling program; providence of on-going information of the process and (intermediate and) end results to decision makers. A concluding conference was organized for decision makers. Deliver accurate and complete facts on cost effectiveness, also compared to other strategies to improve the quality of the educational system. Projects where different capacity development techniques are tested led to different outcomes for pupils. Can this be legitimized? At the start of the project this was discussed and it made clear that for the purpose of knowledge growth is inevitable.

Other challenges are perceiving evaluation as a way to judge project implementers, to reveal areas of project success or failure, and to fear that failure would result in punishment, for instance, the cutting of funding. This is the challenge faced by the researcher whereby some information was hardly given from project implementers, inadequate finances, stringent and donor reporting requirements.

3.5.6 Extent to Which VVOB Projects Improved the School Leadership and Management Improvement of Head Teachers (HTs)

Assessment of how VVOB Projects improved the school leadership and management for HTs was based on the eight dimensions of successful school leadership. These are: Define values and vision to raise expectations, set directions and build trust; Reshape conditions for teaching and learning; Restructure parts of the organization and redesign leadership roles and responsibilities; Enrich the curriculum; Enhance teacher quality; Enhance the quality of teaching and learning; Build collaboration internally; and Build strong relationships outside the school community. The following two tables, table 7 and table 8 show descriptive statistics for group A and descriptive statistics for Group B respectively and where $\mathrm{n}$ stands for total number of respondents. The two tables are formed with help of SPSS and they show only the total number of respondents as they are sixteen (16); sum and mean. They are based on values and as they are in the questionnaire. Those values are 1: Strongly Disagree; 2: 
Disagree; 3: Neutral (Disagree or Agree); 4: Agree and 5: Strongly Agree.

Table 7. Descriptive Statistics for Group A

\begin{tabular}{|c|c|c|c|c|}
\hline Dimension of School Leadership & $\mathbf{n}$ & Sum & Mean & Std. Deviation \\
\hline $\begin{array}{l}\text { Successful school leaders defines values and vision to raise } \\
\text { expectations, set directions and build trust }\end{array}$ & 16 & 67.00 & 4.18 & .65 \\
\hline $\begin{array}{l}\text { Successful school leaders reshape conditions for teaching and } \\
\text { learning }\end{array}$ & 16 & 74.00 & 4.62 & .62 \\
\hline $\begin{array}{l}\text { Heads restructure parts of the organization and redesign } \\
\text { leadership roles and responsibilities }\end{array}$ & 16 & 72.00 & 4.50 & .73 \\
\hline Successful school leaders enrich the curriculum & 16 & 70.00 & 4.37 & .61 \\
\hline Successful school leaders enhance teacher quality & 16 & 68.00 & 4.25 & .77 \\
\hline $\begin{array}{l}\text { Successful school leaders enhance the quality of teaching and } \\
\text { learning }\end{array}$ & 16 & 67.00 & 4.18 & .65 \\
\hline Successful school leaders build collaboration internally & 16 & 71.00 & 4.18 & .81 \\
\hline $\begin{array}{l}\text { Successful school leaders build collaboration internally and } \\
\text { strong leadership outside the school community }\end{array}$ & 16 & 70.00 & 4.37 & .71 \\
\hline
\end{tabular}

Table 8. Descriptive Statistics for Group B

\begin{tabular}{|c|c|c|c|c|}
\hline Dimension of School Leadership & n & Sum & Mean & $\begin{array}{l}\text { Std. } \\
\text { Deviation }\end{array}$ \\
\hline $\begin{array}{l}\text { Successful school leaders defines values and vision to raise expectations, set } \\
\text { directions and build trust }\end{array}$ & 16 & 46.00 & 2.87 & 1.14 \\
\hline Successful school leaders reshape conditions for teaching and learning & 16 & 46.00 & 2.87 & 1.45 \\
\hline $\begin{array}{l}\text { Heads restructure parts of the organization and redesign leadership roles and } \\
\text { responsibilities }\end{array}$ & 16 & 47.00 & 2.93 & 1.23 \\
\hline Successful school leaders enrich the curriculum & 16 & 53.00 & 3.31 & 1.35 \\
\hline Successful school leaders enhance teacher quality & 16 & 50.00 & 3.12 & 1.31 \\
\hline Successful school leaders enhance the quality of teaching and learning & 16 & 46.00 & 2.87 & 1.45 \\
\hline Successful school leaders build collaboration internally & 16 & 45.00 & 2.81 & 1.47 \\
\hline $\begin{array}{l}\text { Successful school leaders build collaboration internally and strong leadership } \\
\text { outside the school community }\end{array}$ & 16 & 49.00 & 3.06 & 1.18 \\
\hline
\end{tabular}

Source: Field Data

The group A is for HTs who were trained as shown by the table 7 shows that the minimum sum is $67 / 80$ related to the mean of $4.18 / 5$ whereas the maximum sum is $74 / 80$ related to the mean of $4.62 / 5$. All the dimensions have the mean located in the value of four (4) this implies that all the respondents generally confirmed the value of Agree to mean that the eight dimensions of successful school leadership are applied by the trained HTs. Meanwhile the table 8 of the control group (Group B) whose HTs are not trained has the minimum sum of $46 / 80$ related to the mean of $2.87 / 5$ and the maximum sum of 53 related to the mean of 
$3.31 / 5$. The general mean of the table 8 is in the range of 2.8 and 3.3 and it is mainly at the rate of three (3) because 2.8 is more than about to be 3 and 3.3 is almost 3 because it does not reach 3.5. Considering the value of 3 as in the questionnaire means Neutral (Disagree or Agree) the respondents are doubtful to disagree or agree therefore, the control group does not respect the eight dimensions of successful school leadership, thus there is failure of school leadership based on the eight dimensions of successful school leadership. The standard deviations also are totally different whereby in the group A they are less than one (1).

The table 9 identifies the Comparison of Group A and Group B based on descriptive statistics. This comparison is mainly based on the sum and mean explained in the table 7 and table 8 . This is a reason why it focuses on the percentage of achievement and that of total distribution.

Table 9. Comparison of Group A and Group B Based on Descriptive Statistics

\begin{tabular}{|c|c|c|c|c|c|c|c|c|}
\hline \multirow[t]{2}{*}{ Dimension of School Leadership } & \multicolumn{2}{|l|}{ Sum } & \multicolumn{2}{|l|}{ Mean } & \multicolumn{2}{|c|}{$\begin{array}{l}\text { Percentage of } \\
\text { achievement }\end{array}$} & \multicolumn{2}{|c|}{$\begin{array}{l}\text { Percentage of } \\
\text { total Distribution }\end{array}$} \\
\hline & $\operatorname{Gr}(\mathbf{A})$ & $\operatorname{Gr}(\mathbf{B})$ & $\operatorname{Gr}(\mathbf{A})$ & $\operatorname{Gr}(B)$ & $\operatorname{Gr}(\mathbf{A})$ & $\operatorname{Gr}(B)$ & $\operatorname{Gr}(\mathbf{A})$ & $\operatorname{Gr}(B)$ \\
\hline $\begin{array}{l}\text { Successful school leaders defines } \\
\text { values and vision to raise } \\
\text { expectations, set directions and build } \\
\text { trust }\end{array}$ & 67 & 46 & 4.18 & 2.87 & 83.75 & 57.50 & 10.47 & 7.19 \\
\hline $\begin{array}{l}\text { Successful school leaders reshape } \\
\text { conditions for teaching and learning }\end{array}$ & 74 & 46 & 4.62 & 2.87 & 92.50 & 57.50 & 11.56 & 7.19 \\
\hline $\begin{array}{l}\text { Heads restructure parts of the } \\
\text { organization and redesign leadership } \\
\text { roles and responsibilities }\end{array}$ & 72 & 47 & 4.5 & 2.93 & 90.00 & 58.75 & 11.25 & 7.19 \\
\hline $\begin{array}{l}\text { Successful school leaders enrich the } \\
\text { curriculum }\end{array}$ & 70 & 53 & 4.37 & 3.31 & 87.50 & 66.25 & 10.94 & 8.28 \\
\hline $\begin{array}{l}\text { Successful school leaders enhance } \\
\text { teacher quality }\end{array}$ & 68 & 50 & 4.25 & 3.12 & 85.00 & 62.50 & 10.63 & 7.81 \\
\hline $\begin{array}{l}\text { Successful school leaders enhance } \\
\text { the quality of teaching and learning }\end{array}$ & 67 & 46 & 4.18 & 2.87 & 83.75 & 57.50 & 10.47 & 8.25 \\
\hline $\begin{array}{l}\text { Successful school leaders build } \\
\text { collaboration internally }\end{array}$ & 71 & 45 & 4.43 & 2.81 & 88.75 & 56.25 & 11.09 & 7.03 \\
\hline $\begin{array}{l}\text { Successful school leaders build } \\
\text { collaboration internally and strong } \\
\text { leadership outside the school } \\
\text { community }\end{array}$ & 70 & 49 & 4.37 & 3.06 & 87.50 & 61.25 & 10.94 & 7.66 \\
\hline Total/640 & 559 & 382 & $\begin{array}{l}\text { Average: } \\
4.36\end{array}$ & $\begin{array}{l}\text { Average: } \\
2.98\end{array}$ & 87.34 & 59.69 & 87.34 & 59.69 \\
\hline Uncovered content & 88 & 258 & & & 12.66 & 40.31 & 12.66 & 40.31 \\
\hline
\end{tabular}

Source: Researcher (2017) 


\section{Macrothink}

The mean score of achievement in the group A are in the range of 4.18 and 4.62 while that of control group are in the range of 2.87 and 3.31 and the overall mean score for group A is 4.36 while for group B is 2.98. (Table 9) This is also another sign of big difference of the performance of school leadership of the two groups and highlighted difference of the group of trained HTs and the control group.

Table 10. Comparison of Group A and B Based on Total Scores

\begin{tabular}{ccc}
\hline Groups & $\begin{array}{c}\text { Mean } \\
\text { Scores }\end{array}$ & $\begin{array}{c}\text { Percentage } \\
(\%)\end{array}$ \\
\hline Group A & 4.36 & 59 \\
Group D & 2.98 & 41 \\
Overall & 7.34 & 100 \\
\hline
\end{tabular}

Figure 1: Comparaison of trained Head teachers(A) and Untrained Head teachers

(B)

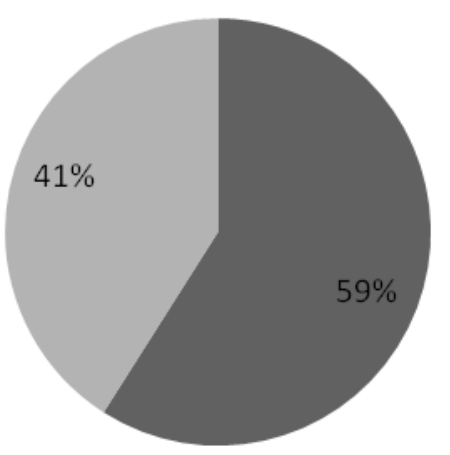

Figure 1. Comparison of Trained Head Teachers(A) and Untrained Head Teachers(B)

Source: Field Data

Table 10 and Figure 1 show that Group A of the trained HTs in the successful school leadership occupies the rate of 4.36 mean scores equivalent to $59 \%$ while of Group B occupies 2.98 mean score equivalent to $41 \%$. Those two groups should have the same mean score when HTs should be trained for each group. The difference found comes from the fact that trained HTs perform successfully.

\subsubsection{Improvement of Sector Education Officers (SEOs)}

The assessment of the improvement of Sector Education Officers (SEOs) is based on characterizing the intervention of the SEOs in dialogues in meetings, workshops, conferences and trainings with HTs, this lead to make SEOs Educational Leadership Facilitators in 
acquiring coaching competencies needed to provide them with inter-vision coaching in their Sectors. Comparing the two Groups of SEOs- the Group A of SEOs trained about school leadership and management by VVOB Rwanda projects and SEOs who compose the control group (Group B) who were not trained.

The following table 10 presents the comparison of coaching competencies of the two groups of SEOs.

Table 11. Comparison of SEOs from Group A and B

\section{S/N Trained SEOs(Group A)}

1 For the meeting the agenda is well prepared and the arrangement of KITs like circle. SEOs try to take a coaching role it means listen to head teachers 'needs and mobilize peer experience to share in order to meet those needs. The SEO is delegating his role successfully to one of the HTs and facilitates the process by asking clarification of questions.

2 SEO facilitates sequence in making dialogue instead of being monologue and every HT contribute in giving their ideas in the sequences.

a. Every time the one who brought the problem (The problem owner) gets the opportunity to explain the problem and related to the eight dimension of the school leadership.

b. The problem is sufficiently explored and all questions necessary for clarification are asked.

c. There is consensus on the essential characteristics of the problem.

d. Different possibilities for solutions are well explored and effectively presented.

e. The problem owner have the opportunity to make his/her own choice about for him/her appropriate solution.

Given the observations above, the quality of communication is well done by SEOs.

5 All group members participate in their own
Non Trained SEO (Group B)

Most SEOs are 'telling' or 'selling'. They take the role of lecturer/teacher, the one who knows and is there to distribute their knowledge. The arrangement of furniture is like in the traditional classroom.

Most of the time SEO is lecturing. Often there is a sequence of monologues more than a dialogue. At the average the SEOs uses $80 \%-90 \%$ of the available time to speak.

a. Most of the time the one who brought the problem (the problem owner get the opportunity to explain the problem.

b. Often the SEO is the one who asks questions for clarification, forgetting all members should get the opportunity to ask those questions.

c. Related to the foregoing item not all essential characteristics are sufficiently explored. Consensus is often the one between SEO and the problem owner.

d. Most of the time more solutions are explored, but often related to the "incomplete" presentation of the problem.

e. Most problem owners make his/her choice and tells that is what (s) he is going to apply in the coming period of time.

There should be summarizing technique to support the quality of communication.

There is most of the time not yet a collective 


\section{Macrothink

individual way. SEOs use group work in their way of participating or group dialogues. teaching methodology. Participation is more intense and collective.

6 In all cases there is respectful and positive atmosphere with participant who are eager to learn and enthusiastic.

7 The rate between $30 \%-40 \%$ is the one confirmed by $13 / 16$ respondents either $81 \%$ to be considered that plays role in the contribution of effective and efficient achievement objectives. The reasons given are that $\mathrm{M} \& \mathrm{E}$ is considered as the pillar to the achievement of what are planned when all means required are available. Other factors that influence the achievement of the project objectives cited are: proper planning, competent staff, clear vision and objectives, sufficient financial resources.

\section{Source: Field Data}

Table 11 identifies outstanding differences between the experimental group of trained SEOs known as Group A and control group of not trained SEOs (Group B) about the coaching role for school leadership. These are dialogues in meetings, workshops, conferences and trainings. The difference resides in the different aspects such as: preparation of meeting agenda; making dialogue; giving opportunity to give explanation(Engaging the participants); facilitating consensus; quality of communication; respectful and positive atmosphere and having $81 \%$ of respondents confirmed that $\mathrm{M} \& \mathrm{E}$ is very important in the rates between $30 \%$ and $40 \%$.

\section{Summary of Findings, Conclusion and Recommendations}

\subsection{Introduction}

This part covers the summary, general conclusion and recommendations. The researcher was interested in finding out the role played by monitoring and evaluation leading to project success and improving school leaderships and management. The result from the study indicates that research objectives have been achieved.

\subsection{Summary of Findings}

In this research study gender was balanced for project implementers and other stakeholder. The gender was 50\% male and 50\% female. Gender for project beneficiaries such as Head Teachers and Sector Education officers was not considered because the nature of information required did not require gender for being relevant. Educational level of respondents showed that a big number of the respondents to mean 55\% were bachelor's degree holders and $13 \%$ who have the higher level than bachelor's degree. This implied that the information given was reliable and valid because they know the value of doing research based on their prior experiences. Working Experiences is higher because 86\% of respondents have between 3-15 years of experience. This shows that the respondents master their duties and responsibilities that guides them to effective and efficient achievement of what they are assigned to do even if professional training was crucial role for SEOs and HTs. 


\subsection{VVOB Rwanda's Monitoring and Evaluation Techniques}

Monitoring and evaluation techniques of VVOB Rwanda projects were good and conducive to the project's success. This is confirmed by the rate of $88.8 \%$ for planning monitoring and

evaluation activities done, those activities are study for baseline data, plan that guides $M \& E$, and the budget for M\&E. Projects monitoring and evaluation process implementation has the rate of $86.5 \%$ to mean that all activities for implementing M\&E were done at that rate and then about reporting, lesson learning from M\&E report, financial means and impacts demonstration are rated at $75 \%$ to imply that they have conducive way of the project success.

Briefly, M\&E tools and techniques are effective for achieving the project success and the general contribution of projects M\&E for project success was rated between $30 \%$ and $40 \%$. This is due to the crucial role of M\&E such as that it helps: planning, monitoring and improving project progress, measuring and increasing project impact, as instrument for advocacy. Other factors that help for achieving project objectives are clear vision and objectives, sufficient financial resources, competent staff, proper planning, expert in M\&E. The few shortcomings from the VVOB monitoring and evaluation are that the finance to carry out $\mathrm{M} \& \mathrm{E}$ is rarely adequate, external evaluators are involved few times when conducting evaluations and not involving project stakeholders in the planning of $\mathrm{M} \& \mathrm{E}$ activities.

\subsection{Challenges faced by VVOB Rwanda's Monitoring and Evaluation Techniques}

Challenges encountered are short duration of the project for measuring learning outcomes' effects, turnover of HTs and SEOs whereby mentors were assigned to new comers. Cultural barrier for using the coaching concept and where happened it was adjusted to the cultural context. Other challenges were perceiving evaluation as a way to judge project implementers, to reveal areas of project success or failure, and to fear that failure would result in punishment, for instance, the cutting of funding. This is the challenge faced by the researcher whereby some information was hardly given from project implementers, inadequate finances, stringent and donor reporting requirements. All education partners such as NGOs, MINEDUC, REB, University of Rwanda, College of Education should be involved in achieving $100 \%$ the school leadership and management.

\subsection{Improvement of the School Leadership and Management}

The research findings revealed that VVOB Rwanda project has played a vital contribution of successful school leadership and management. This was found through the comparison of 16 HTs and SEOs trained (Group A) and 16 HTs and SEOs (Group B) who were not trained about school leadership based on the eight dimensions of successful leadership identified in the research of Day et al. (2009), i.e. Successful leaders: define their values and vision to raise expectations, set direction and build trust; reshape the conditions for teaching and learning; restructure parts of the organization and redesign leadership roles and responsibilities; enrich the curriculum; enhance teacher quality; enhance the quality of teaching and learning; build collaboration internally; build strong relationships outside the school community. The comparison showed that the Group A achieved the successful school 
leadership at the rate of $87.34 \%$ whereas the Group B was at the rate of $59.69 \%$. This is the big difference of how the VVOB Rwanda project played role in the improvement of school leadership.

\section{Conclusion}

Research findings have shown that VVOB's monitoring and evaluation techniques are conducive to the project success. This is due to the practices of monitoring and evaluation tools and techniques used from the project initiation up to the final phase -project close out. When doing monitoring and evaluation in VVOB Rwanda projects as in other activities challenges are raised. The most challenges found in $M \& E$ are inadequate financial resources, fear of evaluation of project implementers thinking that it is the way of judging them and sometimes causing them to have punishment like cutting the project funds, and some other challenges related to the kind of project. For instance the researcher found that when implementing the school leadership project: short time, turnover of HTs and SEOs have been raised and solution have been applied to address those challenges. Finally VVOB Rwanda projects have significantly improved the school leadership and management as it was shown by the difference about performance of school leadership dimensions of trained head teachers and Sector educations officers comparing with those who were not trained.

\subsection{Recommendations}

Having realized the paramount roles of monitoring and evaluation leading to the project success; the relationship between the two variables; the challenges and their related measures to overcome them and the significant improvement of school leadership and management for the head teacher and Sector education officers benefitted from VVOB projects, the researcher recommended the following:

1. Policy makers in project management should have high consideration monitoring and evaluation as way that leads to the project success;

2. NGOs, Civil Society Organization, governments are required to make emphasis on monitoring and evaluation for impact assessment and goal achievement and involve

all project stakeholders in planning, implementation of monitoring and evaluation activities.

3. Project initiators, designers and planners have to prepare M\&E budget with adequate financial resources separated with the budget of the whole project for the M\&E smooth activities;

4. VVOB should involve external evaluators in evaluation, provide adequate finance for $M \& E$ activities and involve all stakeholders in planning of $M \& E$ activities.

5. Project implementers should not consider external evaluators as those who are judging them but as those who are going to see and considers the project activities from out of the box, thus improvement and documentation become successful. 
6. Training needs assessment should be always carried out by education administrators in order to provide trainings when necessary for improvement of education quality, access and equity.

7. Schools and their governing structures must let school leaders lead in a systematic fashion and focus on the instructional and learning processes and outcomes of their schools.

\subsection{Suggestions for Further Studies}

This study was limited to the contribution of monitoring and evaluation to the project success. It also determined the challenges the VVOB Rwanda projects faced in monitoring and evaluating then it shows the improvement of school leadership and management made by VVOB Rwanda projects.

I would suggest that further research would be conducted in making comparison of monitoring and evaluation best practices and M\&E practices made by public institutions. Further research would also empirically determine the actual impact of VVOB Rwanda project on the performance of school leadership and management and students' academic performance considering results from National Examinations.

\section{References}

Atesmen, M. (2008). Global Engineering Project Management. New York: CRC Press. https://doi.org/10.1201/9781420073942

Babbie. (2008). The Basics of Social Research (4th ed.). Chapman University.

Bank, W. (2006). Monitoring and Evaluation project: a step by step Primer on Monitoring, Benchmarking, and Impact Evaluation. Washington DC: World Bank.

Bank, W. (2004). Monitoring and evaluation: Some tools and approaches. Washington DC: World Bank.

Belassi, W., \& Tukel, O. I. (1996). A new framework for determining critical success/failure factors in projects. International Journal of Project Management, 14(3), 141-151. https://doi.org/10.1016/0263-7863(95)00064-X

Bennis, Warren. (1989). On becoming a leader. New York: Addison Wesley.

Britton, B. (2005). Organisational learning in NGOs: Creating the motive, means, and opportunity. Oxford: International NGO Training and Research Centre.

Burke, J. (2004). Educational Research: Quantitative, Qualitative and mixed approaches (4edition). USA: Pearson Education.

Burke, R. (2001). Project Managemen: planning and Control Techniques. South Africa: PROMATEC International. 
Butera B.P. (2013). Project Monitoring and Evaluation. Kigali: Mount Kenya University Crawford, P. and Bryce, P. (2003). Project Monitoring and Evaluation: A method of enhancing the efficiency and effectiveness of aid project implementation. International Journal of Project Management, 363-373.

D.I. Cleland \& R. Gareis. (1995). Global Project Management Handbook. Journal of Engineering and Technology Management, 239-243.

Davidson, E. (2000). Ascertaining causality in theory-based evaluation, in Program Theory in Evaluation: Challenges and Opportunities. New Direction for Evaluation, 2000(87), 17-26. https://doi.org/10.1002/ev.1178

Fox, W., \& Waldt, G.V.D. (2008). A Guide to Project Management. Cape Town: Tuta.

Frimpong, E. (2003). Project Management for Non-Profit Organization. Johannesburg: Repro Centre.

Gakunde. (2012). The role of NGOs in sustainable community development in Rwanda. A case of Kicukiro District. Kigali: Mount Kenya University.

Guba, E.G., \& Lincoln, Y.S. (1989). Fourth Generation Evaluation. USA: Sage Publications Ltd.

Heerkens, G. (2002). Project Management. New York: MCGraw-Hill.

Hisada, N. (2003). Introduction to Social Work Research. Tokyo.

Hunter. (2009). Monitoring and Evaluation: Are We Making Difference? Namibia: Namibia Institute for Democracy.

IFRC. (2011). Project/programme monitoring and evaluation (M\&E). Geneva: International Federation of Red Cross and Red Crescent Societies.

James Tobin. (2014). Management and Leadership Issues for School. NCPEA International Journal of Educational Leadership Preparation, 9(1).

Keeling, R. (2000). Project Management: An International Perspective. London: McMillan Press.

Kotter, J.P. (1990). A Force for Change: How Leadership Differs from Management. Simon and Schluster. New York.

Kotter, J. P. (2001). What leaders really do? Harvard Business Review, 79(11), 85-96.

Khan, K. (2003). Strengthening of Monitoring and Evaluation System. Islamabad.

Khotari, C. (2004). Research Methodology; Methods and Techniques (2 $2^{\text {end }}$ ed.). Jaipur: New Age International Publishers.

Kusek \& Rist. (2004). Ten Steps to a Result-Based Monitoring and Evaluation System. Washington: World Bank. 
Lex Donaldson. (2001). The contingency theory of organizational design: challenges and opportunities. Australian Graduate School of Management in the Universities of New South Wales and Sydney, Australia. https://doi.org/10.4135/9781452229249

Lunenburg, F.C. (2011). Leadership versus Management: A key distinction- at least in theory. International journal of Management, Business and Administration, 14(1), 1-4.

Mackay, K. (2007). How to Build Monitoring and Evaluation System to Support Better Government. Washington DC: World Bank. https://doi.org/10.1596/978-0-8213-7191-6

Marchant, R. E. (2008). Official Statistics and Monitoring and Evaluation Systems in Developing Countries: Friends or Foes? Paris: The Partnership in Statistics for Development in the $21^{\text {st }}$ Century.

Merriam, S. (2009). Qualitative Research: A Guide to Design and Implementation. San Francisco: Jossey-Bass.

Muzinda, M. (2007). Monitoring and evaluation Practices and challenges of Goborone Based Local NGOs Implementing HIV/AIDS Projects in Botswana. Goborone: University of Botswana.

OECD (2009). Creating Effective Teaching and Learning Environments: First Results from TALIS - ISBN 978-92-64-05605-3.

Odera, P., \& Okenyi, S. (2006). Educational Research Method. Kigali: KIE.

O'Sullivan, R. (2004). Practicing Evaluation: A Collaborative Approach. London: Sage Publications Ltd. https://doi.org/10.4135/9781412985468

Psarras J.E., \& P. A. (1999). Towards the Integrated Monitoring and Evaluation IMES: A [30] Real Power. MCB University Press, 991-1008.

Richard Elmore. (2000). Building a new structure for school Leadership. Harvard Graduate school of education.

Rwanda, V. (2012). Annual Report. Kigali: VVOB.

Rwanda, V. (2013). Annual Report. Kigali: VVOB.

Iman Attarzadeh, \& Siew Hock Ow. (2008). Project Management Practices: The Criteria for Success or Failure. Journal of University of Malaya, 1, 235-236.

Shaw, I. (1999). Qualitative Evaluation. London: Sage Publications Ltd. https://doi.org/10.4135/9781849209618

Soumelis, C. (1977). Project Evaluation Methodologies and Techniques. Paris: United Nations.

Tayie, S. (2005). Research Methos and Writing Research Proposals. Cairo: Centre for Advancement of Postgraduate Studies and Research in Engineering Sciences.

Thomas J. Sergiovanni, Paul Kelleher, Matha M. McCarthy \& Frances C. Fowler et al (2011). 
The Educational Governance and Administration (6 ${ }^{\text {th }}$ Edition). (Chap 9)

Turner, J. (1999). The Handbook of Project-Based Management (2 ${ }^{\text {nd }}$ ed.). Maidenhead: McGraw-Hill.

Turner, J. (2006). Toward the theory of project management: The nature of the project. International Journal of Project management, 16, 59-63.

Uitto, J. (2004). Multi-Country cooperation around shaerd waters: Role of Monitoring and Evaluation. Cairo: Global Environment Change.

UNDP. (2009). Handbook on planning, monitoring and evaluationfor development results. New York: UNDP.

UNICEF. (1991). Guide for Monitoring and Evaluation. New York: UNICEF.

Westland, J. (2006). The Project Management Life Cycle: A complete step-by-step Methodology for initiating, planning, executing and closing project successfully. London: Kogan Page Limited.

Wideman, R. (2007). The Project Management Life Cycle by Westland J. Vancouver.

Zadek, S. (1999). Beyond Fourth Generation Evaluation. London: New Economics Foundation.

Zaleznik, A. (1997). Managers and leaders: Are they different? Harvard Business Review, 55, 67-78.

Moiz Bhamani (2012). 'The Difference Between Leadership and Management Schools of thought'. Applied Project. Athabasca University, Centre for innovative www.stellarleadership.com Leaderships \& Management (retrieved on 20.12.2017)

\section{Glossary}

ADF: African Development Foundation

ADRA: The Adventist Development and Relief Agency International

CBC: Competence-Based Curriculum

DFID-UK: UK Government's Department for International Development

EDC: Education Development Center

EFA: Education for All

FAWE RWANDA: Forum for African Women Educationlists Rwanda

FHI: Family for Health International

ICT: Information Communication and Technology 
KIE: Kigali Institute of Education

LOPE: Learning Outcome in Primary Education

M\&E: Monitoring and Evaluation

MINEDUC: Ministry of Education

NGO: Non-Government Organizations

OECD: The Organisation for Economic Co-operation and Development

REB: Rwanda Education Board

SEO: Sector Education officer

SHE: Sustainable Health Enterprise

TVET: Technical Vocational Education Training

VSO: Volunteer Service Overseas

VVOB: Flemish Association for Development Cooperation and Technical Assistance

WDA: Work Development Authority.

\section{Copyright Disclaimer}

Copyright for this article is retained by the author(s), with first publication rights granted to the journal.

This is an open-access article distributed under the terms and conditions of the Creative Commons Attribution license (http://creativecommons.org/licenses/by/3.0/). 